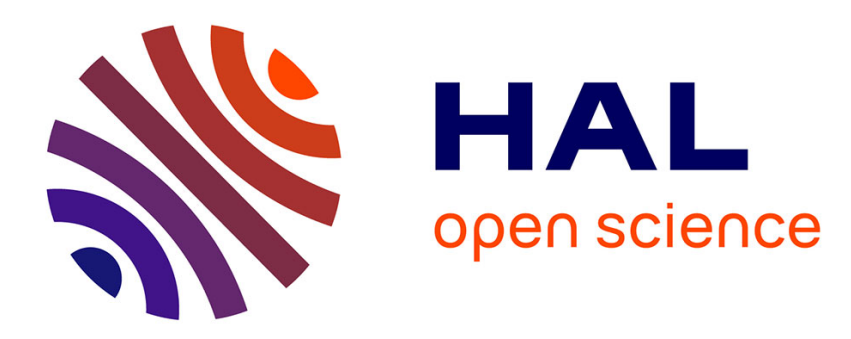

\title{
Soluble phosphorus dynamics in an agricultural watershed
}

L. Jordan-Meille, J.-M. Dorioz

\section{To cite this version:}

L. Jordan-Meille, J.-M. Dorioz. Soluble phosphorus dynamics in an agricultural watershed. Agronomie, 2004, 24 (5), pp.237-248. 10.1051/agro:2004021 . hal-00886048

\section{HAL Id: hal-00886048 \\ https://hal.science/hal-00886048}

Submitted on 1 Jan 2004

HAL is a multi-disciplinary open access archive for the deposit and dissemination of scientific research documents, whether they are published or not. The documents may come from teaching and research institutions in France or abroad, or from public or private research centers.
L'archive ouverte pluridisciplinaire HAL, est destinée au dépôt et à la diffusion de documents scientifiques de niveau recherche, publiés ou non, émanant des établissements d'enseignement et de recherche français ou étrangers, des laboratoires publics ou privés. 


\title{
Soluble phosphorus dynamics in an agricultural watershed
}

\author{
L. JORDAN-MEILLE* ${ }^{a *}$ J.-M. DORIOZ ${ }^{b}$ \\ ${ }^{a}$ ENITA, 1 cours du Général de Gaulle, BP 201, 33175 Gradignan Cedex, France \\ ${ }^{\mathrm{b}}$ INRA, 75 avenue de Corzent, BP 511, 74203 Thonon les Bains, France
}

(Received 3 March 2004; accepted 24 March 2004)

\begin{abstract}
Both particulate phosphorus (PP) and soluble phosphorus (SP) contribute to the eutrophication of water bodies. This research focuses on the mechanisms and factors controlling SP exports at the watershed scale in a case study located in Southern France. Variability in the $\mathrm{P}$ concentrations and fluxes was analysed over a period of 6 years in a 302-ha rural watershed. During most of the hydrological periods, reservoirs and pathways for PP and SP seemed to be different both in time and space; differences were greatest during storm flows of the early wet season. Their high SP fluxes and concentrations were due to the $\mathrm{P}$ released from agricultural soils as shown by a $\mathrm{P}$ mass balance downstream/upstream. During these flushing periods, soluble forms of $\mathrm{P}$ follow a hydrochemical behaviour quite similar to solutes and are transferred in relationship to subsurface flows, as shown by a detailed monitoring of the transition from dry to wet season on an agricultural sub-watershed.
\end{abstract}

soluble phosphorus / watershed / no point source / storm flows / losses

Abbreviations: PP, particulate phosphorus; SP, soluble phosphorus; SRP, soluble reactive phosphorus; TSS, total suspended solids; TP, total phosphorus.

\section{INTRODUCTION}

Most phosphorus (P) transfer from rural watersheds towards aquatic environments occurs during storm-flow periods and in particulate forms $[11,35,56,66]$. In general, the contribution of soluble forms of $\mathrm{P}$ (which include soluble reactive $\mathrm{P}$ - henceforth called SRP) at the outlets of agricultural catchments is low and rarely exceeds $20 \%$ of annual total P (TP) flux $[27,46]$. This supports the standard hypothesis by which the erosion during storm-flow events is assumed to determine particulate P (PP) concentrations, which in turn release and/or control soluble $\mathrm{P}$ (SP) concentrations $\left(\mathrm{H}_{2} \mathrm{PO}_{4}^{-} ; \mathrm{HPO}_{4}^{2-}\right)$ by sorption-desorption processes [67]. However, recent papers show that SP transfer might not be entirely dependent on total suspended solids (TSS) concentrations $[23,58]$.

Diffuse transfers of $\mathrm{P}$ from soils towards surface waters are the result of interactions between diverse types of runoff and easily mobilised P loads located in and on the soils or in the hydrological network. If surface runoff (overland flow) leads to soil erosion, PP and SP are released simultaneously due to interaction between the water and the first few $\mathrm{cm}$ of the topsoil $[15,16,74]$. The amounts thus released are mainly driven by hydrological processes. However, erosive runoff is spatially limited and temporarily confined [23,30]. Other hydrological transfer pathways, non-erosive surface runoff $[9,71]$ and subsurface flow or deep flow mobilise, in theory, only SP and, exceptionally, fine particles. SP always comes from exchanges and solubilisation phenomena which occur as soon as water is in contact with soil or suspended solids [51, 54, 61, 73]. The concentration of SP increases in surface runoff and subsurface runoff when the soils are rich in labile $\mathrm{P}$ [24, 33, 53], which can result either from long-term accumulation (fertilisation) or from temporary over-concentration at the soil surface (i.e., during the manure-spreading period).

In artificially drained areas, drain flow can export large amounts of TP [70]. The fluxes released through these subsurface pathways can be greater than $1 \mathrm{~kg} \mathrm{TP} \mathrm{ha}^{-1} \mathrm{yr}^{-1}[7,59]$, with SRP concentrations as high as $0.4 \mathrm{mg} \mathrm{P} \mathrm{L}^{-1}[1,32]$. A variable proportion of $\mathrm{P}(<10 \%)$ is also exported in particulate form, via the soil's preferential pathways, such as macropores $[22,25,58]$.

In the absence of artificial drainage, deep percolating transfers are in general limited by the P-fixing capacity of soil [16], especially in calcareous areas [41]. Exceptionally, high concentrations and fluxes of SRP $>0.3 \mathrm{mg} \mathrm{PL}^{-1}$ have been reported to leach from specific soil types, for example organic soils [47, 57] or more or less anoxic soils [7, 20, 26, 50]. Due to their high macroporosity, sandy soils appear to be sometimes favourable

* Corresponding author: 1-jordan@enitab.fr 
for subsurface SRP or SP movement [44, 68], but those phenomena are still only approximately quantified and explained.

Some high rates of SP export therefore seem to be related to specific agricultural practices (artificial drainage, over-fertilisation and extreme soil conditions). It is of interest to determine whether in the current situations - that is to say, under nonspecific soil or management conditions - SP movements on the watershed scale are really negligible, or if they are concealed because of speciation changes in the hydrological network [12, 36, 40]. We assume that: (1) there are critical periods which are particularly favourable to the release of SP from soils in runoff whatever the soil conditions are, and (2) consequently, SP dynamics can be relatively independent of PP (or TSS) dynamics.

In order to deal with these assumptions, we studied timespace variability in SP and SRP losses, in a 302-ha agricultural watershed under agricultural and soil conditions believed not to be particularly favourable to SP export. SP dynamics were compared with those of PP and TSS, and also with those of other elements, anions such as $\mathrm{NO}_{3}^{-}$and $\mathrm{Cl}^{-}$, which can help to trace subsurface transfer or leaching in soils. By conducting the study on a watershed scale, it was possible to integrate the diversity of phenomena involved and their cumulated effects.

This extensive research, focused on SP transfer, follows a previous published work which developed a typology relating phosphorus exports to the seasonal changes in runoff characteristics and to the hydrological connections of the studied watershed [30]. We thought that a new contribution was needed to provide additional insights to improve the conceptual model of SP dynamics on the field and watershed scales. This work is supported by a set of original data concerning spatial and temporal variability in SP transfer: (1) 6 years of continuous monitoring at the outlet of the 302-ha watershed justify a comparative study of variability of SP, SRP, PP, TSS, $\mathrm{NO}_{3}^{-}$and $\mathrm{Cl}^{-}$; (2) a detailed monitoring of the cultivated sub-watershed (4.4 ha) during a transition from the dry to wet season, and (3) a calculation of a P mass balance upstream and downstream of the watershed hydrological network during storm flows. This allowed more accuracy when specifying the role of sediments with respect to the control of the forms and amounts of exported $P$.

\section{MATERIALS AND METHODS}

\subsection{Study area}

The Mercube river watershed ( 302 ha) is a tributary of Lake Léman (southern side Long. $06^{\circ} 18^{\prime}$; Lat. $46^{\circ} 21^{\prime}$ 'France). The watershed is characterised by gentle slopes (Fig. 1). Some areas with fine-textured soils are unsuitable for agriculture and covered by forest (123 ha), or are artificially drained ( $3 \mathrm{ha}$ ), and often have a perched water table in winter. The rest of the area is composed of loamy, deep $(1 \mathrm{~m})$, naturally well-drained soils, and covered predominantly with wheat (Triticum Aestivum), corn (Zea Maize ) fields (120 ha) and grassland (50 ha). There are a total of 170 individual agricultural fields averaging 1 ha in size. The agricultural soils are mainly "brown soils" (association of Typic Eutrudepts and Typic Hapludolls, USDA, Soil Taxonomy). Their available P content (Olsen-P) [48] varies from $10 \mathrm{mg} \mathrm{P} \mathrm{kg}^{-1}$ in grassland to $60 \mathrm{mg} \mathrm{P} \mathrm{kg}^{-1}$ in cultivated fields. This last value is greater than the value necessary for optimum yield response [43]. The subsoil of the watershed consists of an impervious calcareous till which favours surface runoff and subsurface flow to the detriment of deep percolation [19]. Because of the gentle slopes and short length of the fields, runoff is generally not able to concentrate and erosion rarely leads to shallow gullies in the fields [71]. Urban impervious surfaces (roofs and roads) cover 9 ha. All the houses in the watershed are connected to a modern sewage system treatment plant (with P removal) whose outlet pours directly into the lake. So there are no point sources discharging into the hydrological network, as confirmed by exhaustive surveys [19]. During the 6-year study, overall land use and crop rotation remained constant (wheat - corn rotation).

A 4.4-ha sub-watershed representative of agricultural land use and with the highest local risk of $\mathrm{P}$ transfer by erosion (5\% slope) was also monitored from Nov. 96 to Jan. 97. The only land use of this sub-watershed was wheat and corn crops. During the monitoring period, winter wheat covered $80 \%$ of the surface area (Fig. 1) while $20 \%$ of the surface was a harvested corn plot, in which the soil had been compacted by wheel tracks where water could concentrate during rainfalls. In contrast, the lumpy structure of the wheat fields was favourable to water infiltration.

\subsection{Hydrological conditions}

The hydrological network (streams and ditches) presents a drainage density of 35 metres ha ${ }^{-1}$, which is considered low [64]. In the lower forested part of the watershed, riverbanks are subject to erosion when water discharge is high. Perennial springs emerge from isolated sandy subsoil layers, which are the predominant sources of stream water under low-flow conditions. The spring waters are rich in calcium bicarbonate.

The watershed hydrology during storm flows from September 95 to January 97 has been described and related to the P fluxes by [30], including the identification of the hydrologically active sub-watersheds and runoff conditions on the fields. Field runoff conditions, based on observations of the appearance of signs of erosion and their positions in the plots [39] were described from 15 fields that represented the agricultural land use.

During the storm flows of the dry summer period, the hydrologically active areas of the watershed were restricted to the impervious urban area (sector A, Fig. 1). The hydrologically active zone increased progressively during the early wet season storms, first to all the flat areas and slope bottoms (sector D, Fig. 1), then to the forest areas (sector B, Fig. 1), and lastly to the slopes of the cultivated areas (sector C, Fig. 1). Each year, the same scenario was observed and was spread over two to six consecutive storm flows, which corresponded to cumulated rainfall of between 150 and $250 \mathrm{~mm}$. This scenario occurred during the falls, causing water tables to recharge. The progressive response of the various sub-watersheds can be explained by the variability in the runoff conditions related to the diversity of the land use and topography of the watersheds. During the early wet season storm flows no signs of erosion were observed for any of the reference fields. 


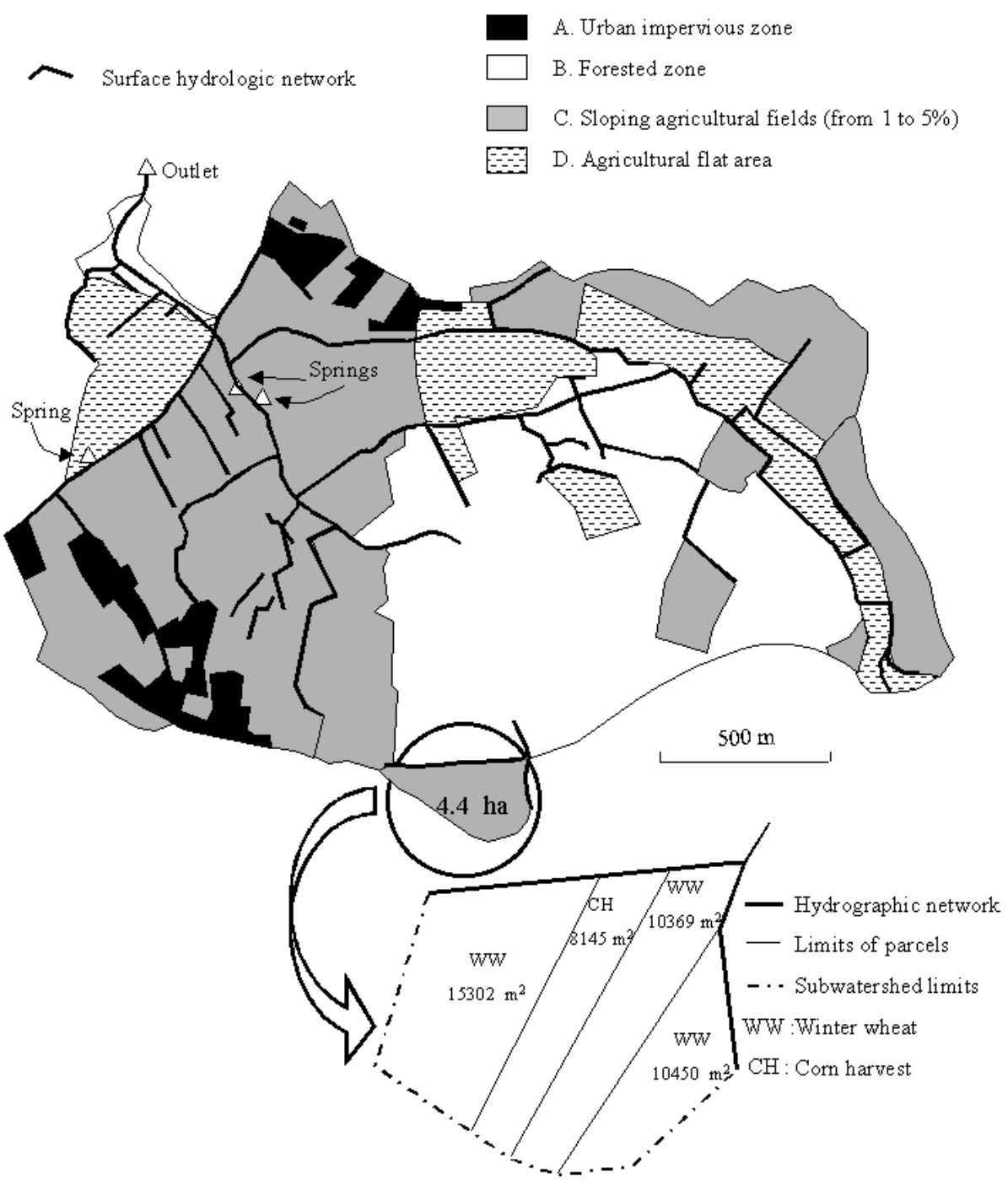

Figure 1. Hydrographic network, soil occupation and morphological characteristics of the watershed [30], with detailed agricultural subwatershed. Land use of winter 96-97.

\subsection{Sampling location and methods}

An automatic sampler was used between 1993 and 1999 at the outlet of the watershed to collect a grab sample every $15 \mathrm{~min}$. Two strategies were used.

(1) From Jan. 1993 to Jan. 1997, low-flow and storm-flow periods were considered separately. During low-flow periods (discharge was constant or slightly decreasing), 32 grab samples were combined to form an 8-hour composite sample and water quality. Analyses were carried out on these composite samples. During storm flows, analyses were performed on 1-h composite samples integrating 4 grab samples.

(2) After Jan. 97, whatever the hydrological conditions, the 8-h composite samples were flow-proportionally mixed to give one weekly composite sample for analysis [12].

The flow-rate monitoring station consisted of a $\mathrm{V}$ - and trapezoidal-notch sharp-crested weir at a drop-off (for small and high discharge, respectively). Water level was recorded with a floating water level gauge.

A 4.4-ha sub-watershed (Fig. 1) was sampled with the same device, and samples were composed according to the first strategy (described for the period Sept. 96-Jan. 97). Local climatic conditions were obtained from a meteorological station established at the study site. Rainwater quality was also routinely analysed.

\subsection{Analytical methods for water quality}

All samples were stored at $4{ }^{\circ} \mathrm{C}$ and then filtered and analysed within one week. This sample storage protocol was found to have a negligible impact on the parameters analysed [49]. The following parameters were measured: Total Suspended Solids (TSS) were measured by filtering water samples of between 100 and $600 \mathrm{ml}$ through pre-weighed GF/F Whatman 
Table I. Concentrations of chemicals and TSS attributed to forested and urban impervious areas [30].

\begin{tabular}{lccccccc}
\cline { 2 - 6 } & $\mathrm{PP}$ & $\mathrm{SRP}$ & $\mathrm{NO}_{3}^{-}$ & $\mathrm{Cl}^{-}$ & $\mathrm{TSS}$ & Area & $\mathrm{n}$ \\
\cline { 2 - 7 } Forest & & & $\mathrm{mg} \mathrm{L}^{-1}$ & & & $\mathrm{ha}$ & \\
Impervious areas & 0.023 & 0.004 & 0.2 & 4.9 & 18 & 123 & 20 \\
\hline
\end{tabular}

PP: Particulate P; SRP: Soluble Reactive P; TSS: Total Suspended Sediments.

filters (pore diameter of $0.7 \mu \mathrm{m}$ ). The $0.7-\mathrm{m} \mathrm{GF/F}$ Whatman filters were preferred to the 0.45 -m filter for high TSS waters (up to $6 \mathrm{~g}$ of TSS $\mathrm{L}^{-1}$ ). Total phosphorus (TP) in unfiltered water, total phosphorus in filtered $(0.7 \mu \mathrm{m})$ water (SP for Soluble Phosphorus) and molybdate-reactive phosphorus considered to be orthophosphates (currently noted SRP for Soluble Reactive Phosphorus) were measured. Interlaboratory comparative $P$ analysis [65] on a wide range of waters (lakes and rivers in France and Switzerland) has shown that there is no significant difference between a $0.7-\mu \mathrm{m}$ filtration and the more classical $0.45-\mu \mathrm{m}$ filtration with regard to TSS, PP and SP measurements. P was analysed according to standard methods [14]. Total and soluble P were converted to orthophosphate by acid persulfate digestion in an autoclave. PP was obtained from the difference between TP and SP. The P content of TSS (in $\mathrm{mg} \mathrm{P} \mathrm{kg}^{-1}$ ) was calculated as the ratio between PP and TSS. $\mathrm{Cl}^{-}$and $\mathrm{NO}_{3}^{-}$were also measured using ion chromatography [13].

\subsection{Calculations}

\subsubsection{Storm-flow event duration}

The storm-flow period was defined as beginning with an increase in water flow and ending during the falling limb of the hydrograph when the concentration of SRP returns to its original level. This approach seemed reasonable as we were studying $\mathrm{P}$ dynamic and because the return to the initial hydrological state sometimes takes many weeks (particularly during the water table recharge periods). This definition was applied regardless of the value of the maximum discharge. Multi-peak events were treated as a single storm-flow event.

\subsubsection{Exports and mean concentrations at the outlet}

During any given period (for example, a storm-flow event), the exported load was calculated by summing up the products of concentration and water volume for each time interval during which the sample was collected [69]. The storm-flow event mean concentration was obtained by dividing the load by the corresponding volume of water. Whatever the sampling strategy used, weekly mean concentrations presented in this paper are always flow weighted.

\subsection{Estimation of the contribution of the active zones}

The mean concentrations at the watershed outlet were simulated for solutes (SP, SRP, $\mathrm{Cl}^{-}$and $\mathrm{NO}_{3}^{-}$) and particles (TSS and PP) from September 96 to January 97, during four storm flows. Computations were based on the export coefficient method:

$$
\mathrm{C}_{\text {mean }}=\Sigma(\mathrm{Cj} \mathrm{Sj}) / \mathrm{S}_{\text {act }}
$$

$\mathrm{Cj}$ : mean concentration corresponding to land use $\mathrm{j}$,

$\mathrm{Sj}$ : active surface area of land use $\mathrm{j}$ during the storm flow,

$\mathrm{S}_{\mathrm{act}}$ : total active surface of the event.

During each storm flow, the diverse land use (j) surfaces (forested, urban and agricultural) involved in runoff $(\mathrm{Sj})$ were determined by mapping the active hydrological sub-watershed. For each of these hydrologically active sub-watersheds, water quality ( $\mathrm{Ci}$ ) was defined, either based on real-time automatic sampling of the agricultural 4.4-ha sub-watershed, or on grab sampling for forest and impervious urban areas (Tab. I). Calculated mean concentrations were compared with measured mean concentrations at the outlet (flow-weighted concentrations) to examine if the concentrations observed at the outlet of the whole basin could be explained by those released by the active areas.

The method used to calculate $\mathrm{P}$ concentrations oversimplifies the diversity of the land use in the watershed. First, assimilating the agricultural water quality with that of the 4.4-ha sub-watershed constitutes a simplifying hypothesis that overestimates the concentration of TSS and PP (this sub-watershed has the highest potential for erosion of the whole agricultural area). Another simplifying hypothesis concerns the quality of runoff from impervious surfaces ( 9 ha) that was chosen to be equal to that of rainfall (no accumulated deposits during a wet period).

\section{RESULTS}

\subsection{Overview of watershed exports}

Table II shows, for the period 1993-1998, (1) the annual mean concentrations of the water quality parameters measured at the outlet and (2) the corresponding agricultural export coefficients. Two years of data have been added to those presented by [30] , allowing a better characterisation of the watershed and new insights into SP dynamics.

TSS exports from the whole basin remained below $500 \mathrm{~kg} \mathrm{ha}^{-1}$ for 4 years out of 6 , and never exceeded $900 \mathrm{~kg} \mathrm{ha}^{-1}$. If the entire TSS flux is attributed to surface erosion of agricultural fields, which corresponds to an overestimation (disregarding forest and river bank erosion), the mean erosion rate would reach $820 \mathrm{~kg} \mathrm{ha}^{-1}$ of cultivated area, a value within the usual range 
Table II. Mean annual exports of measured chemicals, rainfall and volume of water at the outlet of the watershed, from 1993 to 1998.

\begin{tabular}{|c|c|c|c|c|c|c|c|c|c|}
\hline & & \multirow[b]{2}{*}{ TSS } & & & & & & \multirow[b]{2}{*}{ SRP/SP } \\
\hline & & & PP & $\mathrm{SP}$ & SRP & $\mathrm{N}-\mathrm{NO}_{3}^{-}$ & $\mathrm{Cl}^{-}$ & $\mathrm{PP} / \mathrm{TP}$ & \\
\hline & Flow-weighted mean $\mathrm{mg} \mathrm{L}^{-1}$ & 150 & 0.111 & 0.031 & 0.020 & 3.4 & 13.5 & 0.79 & 0.65 \\
\hline & Stand. dev. mg L ${ }^{-1}$ & 76 & 0.032 & 0.005 & 0.004 & 0.5 & 2.8 & 0.05 & 0.04 \\
\hline & Relative stand dev \% & 50 & 29 & 16 & 19 & 14 & 21 & 6 & 6 \\
\hline Export coefficients & /302 ha of tot surface & 421 & 0.311 & 0.09 & 0.06 & 9.5 & 37.9 & & \\
\hline \multirow[t]{5}{*}{$\mathrm{kg} \mathrm{ha}^{-1} \mathrm{yr}^{-1}$} & /155 ha of agric. surf. & 820 & 0.605 & 0.17 & 0.11 & 18.4 & 73.8 & & \\
\hline & & $\begin{array}{l}\text { Rain } \\
\mathrm{mm}\end{array}$ & $\begin{array}{c}\text { Vol. wat. } \\
\mathrm{m}^{3} \\
\end{array}$ & & & & & & \\
\hline & Mean & 1033 & 848167 & & & & & & \\
\hline & Stand. dev & 99 & 185895 & & & & & & \\
\hline & Relative stand dev $\%$ & 10 & 22 & & & & & & \\
\hline
\end{tabular}

PP: Particulate P; SP: Soluble P; SRP: Soluble Reactive P; TSS: Total Suspended Sediments.

of erosion values measured for agricultural fields with slight slopes, in this part of Europe [45].

The mean PP concentration for the six years $\left(111 \mu \mathrm{g} \mathrm{P} \mathrm{L}^{-1}\right)$ was far greater than that of SP $\left(31 \mu \mathrm{g} \mathrm{P} \mathrm{L}^{-1}\right)$ and SRP $(20 \mu \mathrm{g}$ $\left.\mathrm{P} \mathrm{L}^{-1}\right)$. SP was made up of about $65 \% \mathrm{SRP}$. This proportion remained stable between the annual means $(65.4 \% \pm 4)$.

The mean PP/TP ratio was $79 \%$ and was also relatively stable on the annual scale, as shown by the relative standard deviation (= standard deviation / mean) in Table II ( $n=6$, Rel. Stand. Dev. $=6 \%$ ). However, this ratio was highly variable (from 20 to $90 \%, \mathrm{n}=312$, Rel. Stand. Dev. $=24 \%$ ) when all the weekly means over the 6-year period were considered. These values are usual for agricultural watersheds [56].

TP export coefficients were always below $0.7 \mathrm{~kg} \mathrm{P} \mathrm{ha}^{-1} \mathrm{yr}^{-1}$, with an average of $0.4 \mathrm{~kg} \mathrm{P} \mathrm{ha}^{-1} \mathrm{yr}^{-1}$ for the entire watershed, i.e. two- to three-fold the natural background noise values measured locally, in forest or pasture watersheds [4, 49]. Such $\mathrm{P}$ fluxes corresponded to the lowest of the values reported by [21] or [28] in a literature review of a hundred rural watersheds used mainly for farming. Similarly, $\mathrm{NO}_{3}^{-}$concentrations remained quite low $\left(\mathrm{N}=3.4 \mathrm{mg} \mathrm{N}-\mathrm{NO}_{3}^{-} \mathrm{L}^{-1}\right)$ for a cropping zone.

If the entire TP flux is attributed to the agricultural fields, the mean export coefficient would be $0.76 \mathrm{~kg} \mathrm{TP} \mathrm{ha}^{-1} \mathrm{yr}^{-1}$, a low value compared with those measured in watersheds with similar land uses in which fluxes often exceeded $1 \mathrm{~kg} \mathrm{P} \mathrm{ha}^{-1} \mathrm{yr}^{-1}$ $[32,37,52]$. The areal export values of $\mathrm{SP}$ and $\mathrm{NO}_{3}^{-}$are also in the lower range of values found in the literature for equivalent land use. All these results highlight the relatively moderate intensity of transfers in the watershed studied.

There was no temporal pattern during the study period, although variability of different parameters could reach high values (Tab. II). The relative standard deviation showed that the variability of annual TSS concentrations was quite high (50\%) compared with annual rainfall (10\%). This confirms the importance of seasonal distribution of rainfall on erosion. For other water quality parameters, the relative standard deviations were similar to that of water volume (22\%): $\mathrm{Cl}^{-}$(21\%), SRP
$(19 \%)$ or SP $(16 \%)$ and $\mathrm{NO}_{3}^{-}(14 \%)$. Variability of PP $(29 \%)$ was intermediate and twice as much as that of SP.

Some variations over the 6 years were linked to annual water volume. The mean annual concentration of PP showed a high linear positive correlation with total annual water volumes $\left(\mathrm{R}^{2}=\right.$ 0.96). The same trend was observed for TSS concentrations, except for one year $\left(\mathrm{R}^{2}=0.96\right)$. In contrast, $\mathrm{Cl}^{-}$concentrations showed a negative linear correlation with water volume $\left(\mathrm{R}^{2}=\right.$ $0.84)$. SP and SRP had a very weak positive relationship with water volume $\left(\mathrm{R}^{2}<0.4\right)$ while $\mathrm{NO}_{3}^{-}$was not related to water volume. Consequently, the PP/SP ratio tended to increase (from one-fold to two-fold) with the annual rainfall $\left(\mathrm{R}^{2}=0.88\right)$ and volumes of water flowing at the outlet $\left(\mathrm{R}^{2}=0.68\right)$. The differences in mean concentration-water volume relationships, like the differences in variability, reveal the diversity of the patterns of storage and transport, on the watershed scale. They also show the specificity of SP and SRP whose overall behaviour was sometimes closer to soluble $\mathrm{NO}_{3}^{-}$and $\mathrm{Cl}^{-}$than to particulate forms.

\subsection{Seasonal dynamics of SP concentrations at the outlet}

The proportion of the annual SP and PP export that occurred during storm flows was 83 and $96 \%$, respectively. Six years of variations in weekly mean SRP concentration (Fig. 2A) showed a succession of narrow peaks corresponding to storm-flow periods. Between the peaks, i.e. at low flow $\left(<10 \mathrm{~L} \mathrm{~s}^{-1}\right)$, water quality was characterised by a low SRP mean concentration $(\mathrm{n}=$ 140 , mean $=8 \mu \mathrm{g} \mathrm{L}^{-1}, \mathrm{Std} \mathrm{dev}=12 \mu \mathrm{g} \mathrm{P} \mathrm{L}^{-1}$ ), a concentration close to or even lower than that of spring-water grab samples $\left(\mathrm{n}=79\right.$, mean $\left.=10 \mu \mathrm{g} \mathrm{P} \mathrm{L}^{-1}, \mathrm{Std} \mathrm{dev}=11 \mu \mathrm{g} \mathrm{P} \mathrm{L}^{-1}\right)$. Total-P concentrations were very stable within the same week [31] and did not show the typical temporal pattern of brooks polluted by point sources (daily and weekly cycles of concentrations during low-flow periods) [12].

During high flows, the amplitude of the SRP peaks (each data point is a weekly mean) greatly varied (maxima from 10 to $\left.151 \mu \mathrm{g} \mathrm{P} \mathrm{L}^{-1}\right)$ but had no obvious correlation $(\mathrm{r}<0.1)$ either 
Table III. Hydrochemical characteristics of different kinds of storm flows recorded at the outlet of the 302-ha watershed. Data are based on 1-h pooled samples.

\begin{tabular}{|c|c|c|c|c|c|c|c|c|c|c|c|c|c|c|c|c|c|c|}
\hline \multirow{3}{*}{$\begin{array}{c}\text { Date of } \\
\text { storm-flow }\end{array}$} & \multicolumn{3}{|c|}{ Hydrology } & \multicolumn{2}{|c|}{ Extreme values } & \multicolumn{6}{|c|}{ Flow-weighted mean concentrations } & \multicolumn{6}{|c|}{ Daily exportations } & \multirow{3}{*}{$\begin{array}{c}\% \text { SP } \\
\text { SP/TP } \\
\% \\
\end{array}$} \\
\hline & \multirow{2}{*}{$\begin{array}{l}\text { Vol } \\
\mathrm{m}^{3}\end{array}$} & \multirow{2}{*}{$\begin{array}{c}\text { Discharge }_{\max } \\
\mathrm{Ls}^{-1}\end{array}$} & \multirow{2}{*}{$\begin{array}{c}\text { duration } \\
\mathrm{h}\end{array}$} & {$[\mathrm{SRP}]_{\max }$} & {$\left[\mathrm{NO}_{3}\right]_{\max }$} & {$[\mathrm{PP}]$} & {$[\mathrm{SP}]$} & {$[\mathrm{SRP}]$} & {$\left[\mathrm{NO}_{3}^{-}\right]$} & {$\left[\mathrm{Cl}^{-}\right]$} & [TSS] & PP & SP & SRP & $\mathrm{NO}_{3}^{-}$ & $\mathrm{Cl}^{-}$ & TSS & \\
\hline & & & & \multicolumn{2}{|c|}{$\mathrm{mg} \mathrm{L}^{-1}$} & \multicolumn{6}{|c|}{$\mathrm{mg} \mathrm{L}^{-1}$} & \multicolumn{6}{|c|}{$\mathrm{kg} \mathrm{day}^{-1}$} & \\
\hline $5^{\text {th }}$ nov 96 & 251 & 11,3 & 24 & 0.065 & 2.6 & 0.079 & 0.08 & 0.004 & 2.8 & 15.1 & 28 & 0.02 & 0.02 & 0.01 & 0.7 & 3.8 & 7 & 50 \\
\hline $12^{\text {th }}$ nov 96 & 16831 & 241 & 36 & 0.856 & 8.2 & 0.192 & 0.156 & 0.089 & 4.2 & 14.8 & 50 & 2.1 & 1.8 & 1.5 & 70.2 & 249.4 & 834 & 45 \\
\hline $23^{\text {rd }} \operatorname{dec} 96$ & 31416 & 450 & 88 & not avail. & 3.6 & 0.132 & 0.052 & 0.010 & 0.5 & 2.0 & 40 & 1.1 & 0.4 & 0.3 & 16.6 & 62.6 & 1251 & 28 \\
\hline $19^{\text {th }}$ jan 97 & 115650 & 800 & 103 & 0.365 & 4.5 & 0.283 & 0.051 & 0.008 & 0.8 & 2.0 & 97 & 7.6 & 1.4 & 0.9 & 91.3 & 228.4 & 1119 & 15 \\
\hline & \multicolumn{9}{|c|}{ Storm-flow caused by impervious urban surface runoff } & \multicolumn{9}{|c|}{ whole surface without signs of erosion } \\
\hline & \multicolumn{9}{|c|}{ Storm-flow of fall recharge period } & \multicolumn{9}{|c|}{ Water coming from the whole surface with visible erosion symptoms } \\
\hline
\end{tabular}

PP: Particulate P; SP: Soluble P; SRP: Soluble Reactive P; TSS: Total Suspended Sediments.
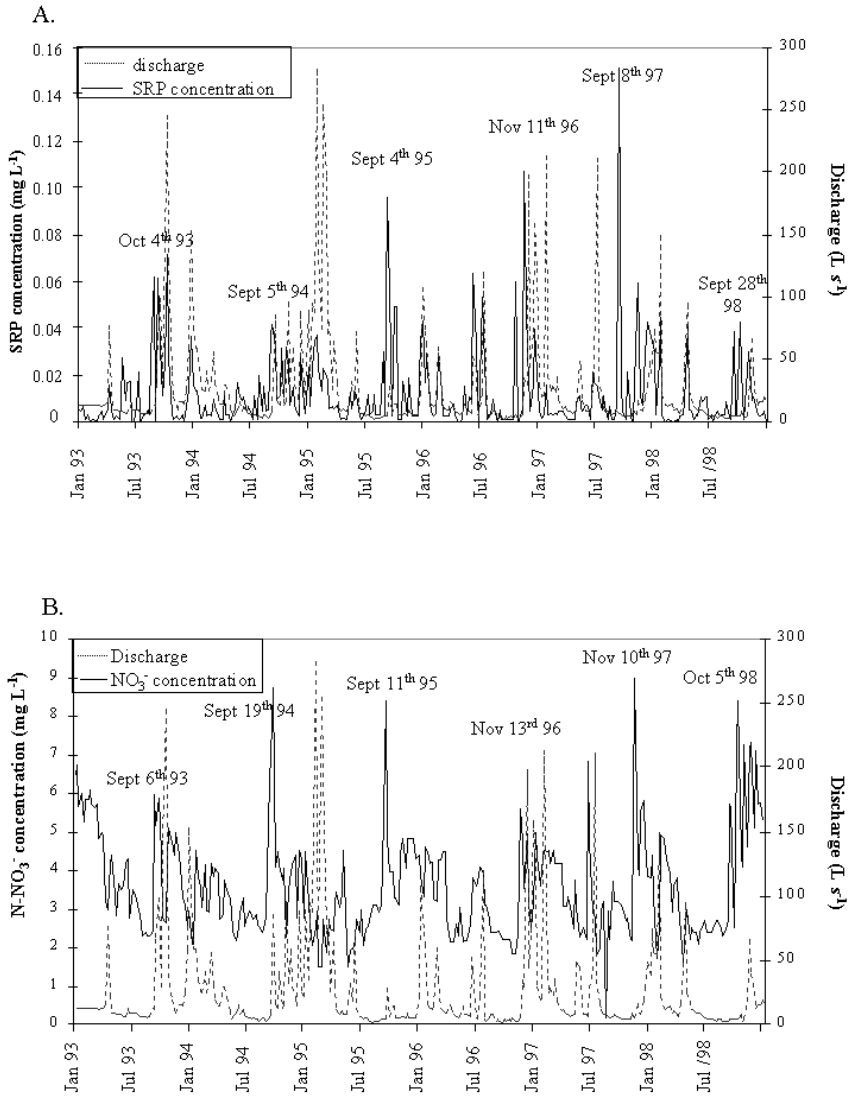

Figure 2. Evolution of Soluble Reactive Phosphorus (A.) and nitrates (B.); weekly mean concentration and discharge at the outlet of the watershed from 1993 to 1998.

with PP or water discharge (Fig. 2). The six maximum mean concentrations all occurred during the early wet season storm flows (the autumn period). During these events, the maximum SRP concentrations of the individual 8-h pooled samples reached extremely high values $\left(85,130,180\right.$ and $363 \mu \mathrm{g} \mathrm{P} \mathrm{L}{ }^{-1}$ from 1993 to 1996 , respectively) with correspondingly high values for the SP/PP ratio (64\%, 30\%, 45\% and 52\% from 1993 to 1996 , respectively). The two or three storm flows subsequent to these post-summer periods also exhibited relatively high SRP concentrations ( 80 to $100 \mu \mathrm{g} \mathrm{P} \mathrm{L}^{-1}$ on average), i.e. twice as high as the other storm flows. Similarly, the low flows between these highly-concentrated storm flows had 5 to 10 times higher SRP concentrations than the usual low flows.

This autumn rainy period corresponds to a recharge period, characterised by the rewetting of soils. It also exhibited particular properties with $\mathrm{NO}_{3}^{-}$concentrations that also presented annual peaks occurring within the same month (Fig. 2B). The concentration dynamics, however, differed from those of SRP, the maximum concentrations being reached between storm flows. This $\mathrm{NO}_{3}^{-}$behaviour is related to known flush dynamics $[8,42]$ : the rewetting of soils results in a sudden increase in $\mathrm{N}$ mineralisation and, as this often coincides with a reduced $\mathrm{N}$ uptake, the transport of water through soil provokes a $\mathrm{N}$ flush. The dynamics of $\mathrm{Cl}^{-}$was quite similar to $\mathrm{NO}_{3}^{-}$dynamics (linear positive correlation between their weekly mean concentrations, $\mathrm{R}^{2}=0.4$ ), with seasonal variations indicating high values (20 $\mathrm{mg} \mathrm{L}^{-1}$ ) during the autumn periods and lower values (10 $\mathrm{mg} \mathrm{L}^{-1}$ ) at the end of the winter period (data not shown). We can therefore assume that $\mathrm{NO}_{3}^{-}$and $\mathrm{Cl}^{-}$were subject to the same leaching process due to the same adsorption mechanism on the soil solid phase.

\subsection{Specificity of storm flows during the early wet season}

In spite of the relatively low volumes of water produced during the storm flows of the early wet season (on average $7 \%$ of the annual volumes of water at the outlet), and despite the small number of storm flows ( 2 to 6 out of an annual total of about $40)$, an average of $14 \%$ of the SRP annual flux was exported during this period. $\mathrm{P}$ dynamics during the autumn period of 1996 is given here as an example: an early wet season storm flow (12th Nov. 96) is compared in Table III with a previous minor urban runoff event (5th Nov. 96) and with two subsequent storm flows in which active zones were extended to all of the watershed. The four storm flows show a progressive increase in the hydrologically active area of the watershed : sector A (Fig. 1) is involved in the storm flow of 5th Nov. 96, sectors A and D in 12th Nov. 96 and all sectors in the last two storm flows. Signs of erosion were observed only for the last storm flow (19th Jan. 97). 
Table IV. Hydrochemical characteristics of different kinds of storm flows recorded at the outlet of the 4.4-ha agricultural subwatershed. Data are based on 30-min pooled samples.

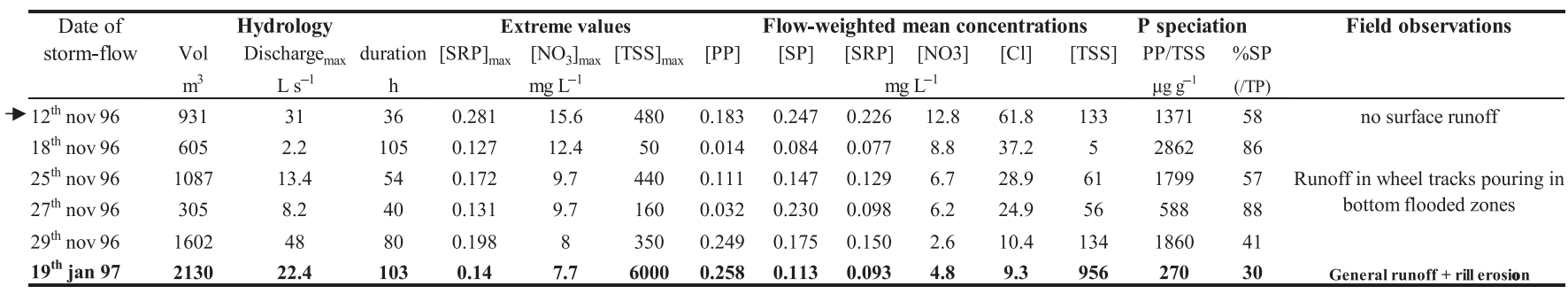

PP: Particulate P; SP: Soluble P; SRP: Soluble Reactive P; TSS: Total Suspended Sediments.

The autumn recharge storm flow differed from the previous or subsequent storm flows in terms of its high mean concentration of soluble elements and SP/TP ratio. The mean SP/TP ratio of the 12th Nov. 96 storm flow (45\%) was comparable with that of the 5th Nov. 96 urban storm flow (50\%) but considerably greater than the later storm flows (28 and $15 \%$, respectively). SRP, $\mathrm{NO}_{3}^{-}$and $\mathrm{Cl}^{-}$concentrations were at least seven times greater than those of the last two storm flows. This difference in concentration of solutes explains why the daily exportation of the 12th Nov. 96 storm flow remained at a high level in SP and SRP compared with the subsequent storm flows, in spite of lower discharge, lower volume and a lower hydrologically active area. The daily exportations were also considerably greater than those of the urban storm flow (10 to 100 times). The low TP export values during the urban storm flow (Tab. III) is representative [29] of the low amount of TP usually accumulated on the urban areas of the Mercube watershed (the maximum observed was $160 \mathrm{~g}$ of TP). Consequently, the urban sub-watershed had little effect on exports during storm flows of the early wet period and wet period.

The differences observed during 1996, between the early wet season storm flows and the following ones, can be applied to the whole period studied. Figure 3 was established on the basis of the 15 storm flows which had been subject to field monitoring (Sept. 1995-Jan. 1997), making it possible to classify them depending on the active zones and the kind of runoff. The early wet season storm flows can be clearly distinguished from subsequent storm flows with active areas extended to the whole basin, by high concentrations in $\mathrm{NO}_{3}^{-}$(all above $4 \mathrm{mg} \mathrm{N}-\mathrm{NO}_{3}^{-}$ $\left.\mathrm{L}^{-1}\right), \mathrm{Cl}^{-}\left(>12 \mathrm{mg} \mathrm{L}^{-1}\right), \mathrm{SRP}\left(>50 \mu \mathrm{g} \mathrm{L}^{-1}\right)$, and the high contribution of SP to the TP exports $(>35 \%)$. In consequence, the storm flows of the early wet period appeared to be especially efficient at transferring solutes and particularly dissolved forms of $\mathrm{P}$. We can assume that these properties indicate a temporary over-accumulation of SP on the watershed. The P thus stored seems to be easily released and mobilised by storm-flow events in which overland flows play only a minor part.

\subsection{SP emissions in an agricultural sub-watershed}

An agricultural sub-watershed of 4.4 ha (Fig. 1) was continuously monitored in 1996 as soon as it became hydrologically active (12th Nov. 96, first storm flow of the wet period) until
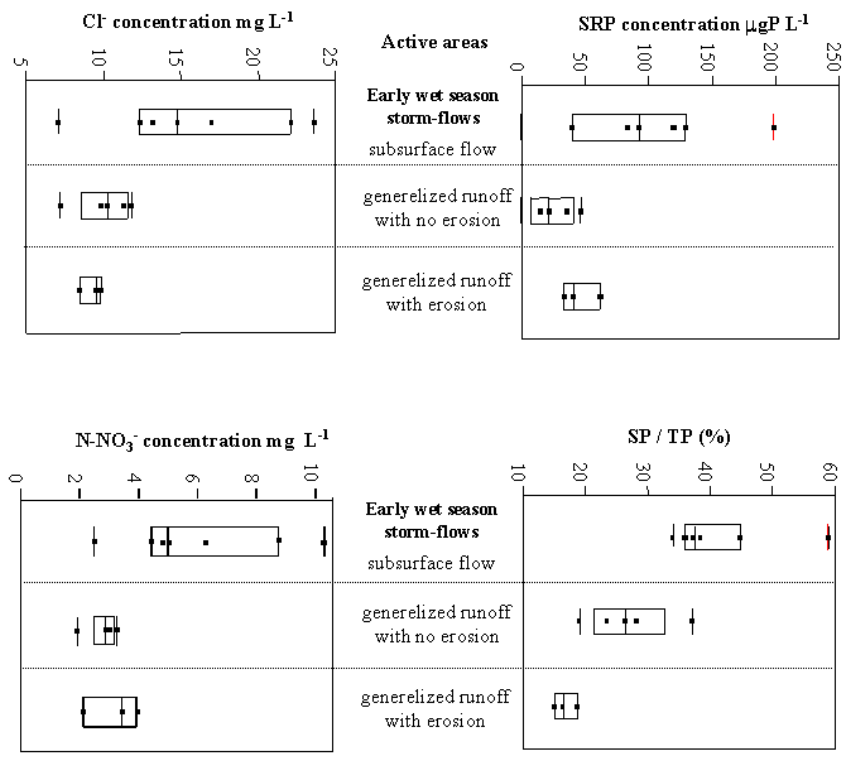

Figure 3. Hydrochemical characteristics of the early wet season storm flows compared with other kinds of storm flows at the outlet of the watershed. Each piece of data corresponds to a given stormflow from Sept. 95 to Jan. 97. Concentrations are flow weighted.

the appearance of the first signs of erosion (erosive storm flow, 19th Jan. 97). The first storm flow was characterised by very high mean concentrations of soluble elements (flow-weighted value, Tab. IV), with SRP maximum values of $281 \mu \mathrm{g} \mathrm{P} \mathrm{L}{ }^{-1}$. During this same storm flow, the SP (composed of $80 \%$ SRP) was predominant (58\% of TP). Such high values of SP/TP remained during the three subsequent storm flows (from Nov. 18th to Nov. 27th). Grab samples collected out of other agricultural sub-watersheds for three years [30], confirmed the preponderance of SP $(n=56$, mean SP/TP $=56 \%$, Std Error $=4)$ and the relatively high concentrations of $\mathrm{SP}(\mathrm{n}=56$, mean $=$ $52 \mu \mathrm{g} \mathrm{P} \mathrm{L}^{-1}$, Std Error $=5$ ). The succession of storm flows studied in 1996 was also characterised by a gradual decrease in the mean concentrations of $\mathrm{NO}_{3}^{-}$and $\mathrm{Cl}^{-}$(Tab. IV). This decrease indicated that it became increasingly difficult for the runoff water to transfer soluble elements, reflecting the fact that the soil sources of solutes were gradually being depleted. The same trends could be observed for SRP and SP. All these storm flows 


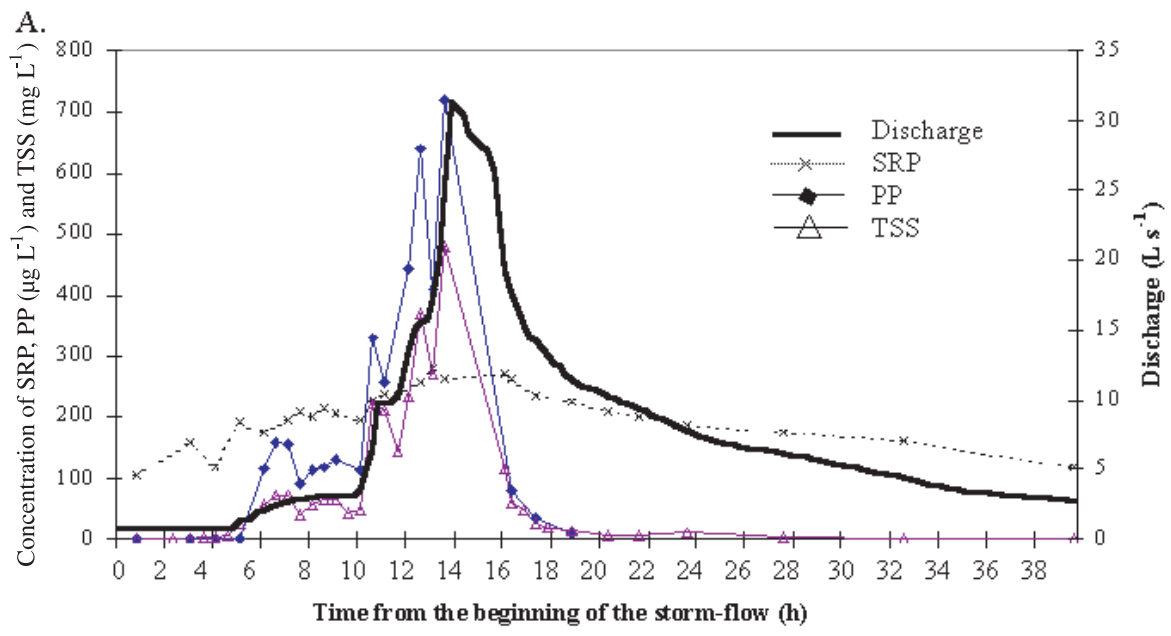

B.

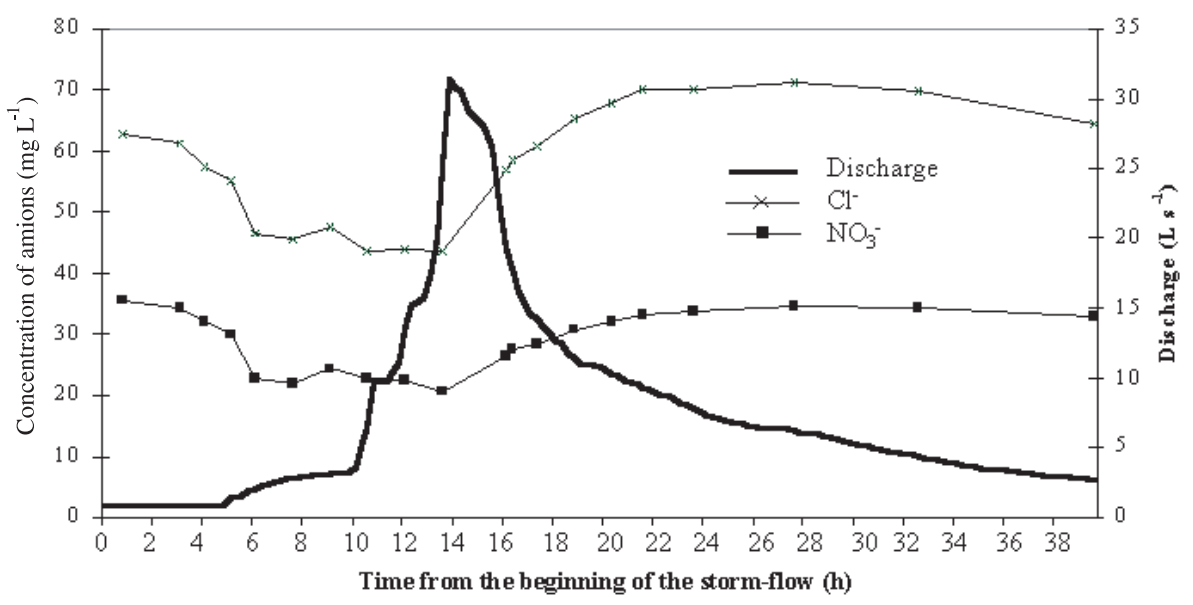

Figure 4. Evolution of Particulate $P$, soluble reactive $P$ and total suspended solids (A.) and solutes (B.) during the 12 th Nov. 96 storm flow at the outlet of the 4.4 ha agricultural sub-watershed.

show that an agricultural watershed can generate high and sometimes very high SP concentrations.

The erosive storm flow of the 19th Jan. 97 marked a considerable change in the hydrochemical properties. This event was distinguishable above all by a large number of signs indicating general overland flow, by its very high TSS concentrations (max. of $6 \mathrm{~g} \mathrm{P} \mathrm{L}^{-1}$ ), PP concentrations ( $\max$ of $1.2 \mathrm{mg} \mathrm{P} \mathrm{L}^{-1}$ ) and by a low $\mathrm{P}$ content of the TSS $\left(<300 \mu \mathrm{g} \mathrm{g}^{-1}\right.$ on average, i.e. twice as low as in the other storm flows). Indeed, except during storm flows associated with signs of erosion ( 2 to 3 times a year), $\mathrm{P}$ inputs from agricultural diffuse sources during storm flows seemed to occur in predominantly soluble form.

The detailed monitoring of concentrations during the first storm flow of the period (12th Nov. 96) is shown in Figure 4A-B. The various forms of $\mathrm{P}$ (Fig. 4A) were more concentrated between $10 \mathrm{~h}$ and $18 \mathrm{~h}$. Conversely, the $\mathrm{NO}_{3}^{-}$and $\mathrm{Cl}^{-}$were diluted at the storm-flow peak by a factor of two (Fig. 4B) which is a typical pattern for these ions. Soluble forms of $\mathrm{P}$ varied independently from PP and TSS although current models describe them as closely related [55, 60, 62]. Indeed, SRP and
SP concentrations evolved very slowly and steadily, as opposed to those of PP and TSS, which responded in bursts to each change of water discharge. The maximal SRP concentration $\left(0.3 \mathrm{mg} \mathrm{P} \mathrm{L}{ }^{-1}\right)$ and SP concentration were reached during the peak flow, but during the recession concentrations remained very high ( $\left.>0.2 \mathrm{mg} \mathrm{P} \mathrm{L}^{-1}\right)$, close to the peak values. This was not the case for PP or TSS concentrations, which soon went back to values close to the background level; respectively, 0.01 and $5 \mathrm{mg} \mathrm{P} \mathrm{L}^{-1}$. As a consequence, $\mathrm{PP}$ concentration only exceeded SP concentration for $3 \mathrm{~h}$ and, on the flow-event scale, the mean SP concentration was greater (30\%) than that of PP.

The fact that unusually high SP and SRP concentrations were maintained during the recession limb over long periods of time $(>10 \mathrm{~h})$ in the absence of TSS reveals a decoupling of soluble and particulate forms of $\mathrm{P}$. The absence of signs of erosion, superficial runoff observed only at slope bottoms and the high concentration of $\mathrm{NO}_{3}^{-}$and $\mathrm{Cl}^{-}$associated with the recession, all suggest that the subsurface flow was the main pathway for water to the slope bottom. The transferred SP may therefore be the result of (1) general subsurface emission and transport 
Table V. Comparison between the mean concentration of runoff on the active areas ( $\Sigma$ A.A.) and the mean flow-weighed concentration at the outlet of the 302-ha catchment.

\begin{tabular}{|c|c|c|c|c|c|c|c|c|c|c|}
\hline \multirow[b]{3}{*}{ date } & \multicolumn{2}{|c|}{ PP } & \multicolumn{2}{|c|}{ SRP } & \multicolumn{2}{|c|}{$\mathrm{NO}_{3}^{-}$} & \multicolumn{2}{|c|}{$\mathrm{Cl}^{-}$} & \multicolumn{2}{|c|}{ TSS } \\
\hline & \multicolumn{10}{|c|}{$\mathrm{mg} \mathrm{L}^{-1}$} \\
\hline & $\Sigma$ A.A. & Outlet & $\Sigma$ A.A. & Outlet & $\Sigma$ A.A. & Outlet & $\Sigma$ A.A. & Outlet & $\sum$ A.A. & Outlet \\
\hline $12^{\text {th }}$ Nov 96 & 0.11 & 0.191 & 0.13 & 0.13 & 7.3 & 6.3 & 36 & 22,2 & 79 & 249 \\
\hline $18^{\text {th }}$ Nov 96 & 0.01 & 0.026 & 0.04 & 0.04 & 5,0 & 5,0 & 22 & 24 & 7 & 22 \\
\hline $27^{\text {th }}$ Nov 96 & 0.03 & 0.135 & 0.05 & 0.021 & 2.9 & 3.2 & 13 & 12 & 33 & 165 \\
\hline $19^{\text {th }}$ Jan 97 & 0.12 & 0.283 & 0.04 & 0.033 & 2.2 & 3.4 & 7 & 8 & 427 & 415 \\
\hline
\end{tabular}

PP: Particulate P; SRP: Soluble Reactive P; TSS: Total Suspended Sediments.

or (2) release of $\mathrm{P}$ from the soil at the slope bottom. In detail, $\mathrm{NO}_{3}^{-}$or $\mathrm{Cl}^{-}$and SRP behaved slightly differently, because the binding capacity of the soil is selective for SRP and/or because $\mathrm{NO}_{3}^{-}$or $\mathrm{Cl}^{-}$are distributed over a greater depth than SRP and can be leached more deeply.

\subsection{Balance input/output during some storm flows}

It was important to estimate whether the concentration of SP observed at the outlet of the whole basin could be explained by the SP content of the runoff emitted by the active areas involved in a given event. To test this, we compared (Tab. V) the mean flow-weighted $\mathrm{P}$ concentrations measured at the outlet with calculated mean concentrations simulating the sum of the contributions of the diverse active areas (calculated according to Eq. (1)). The balance measured/calculated concentrations is evaluated for each storm flow that occurred between the early wet season storm flow of 12th Nov. 96, up to the erosive storm flow of 19th Jan. 97. The same approach was used for $\mathrm{Cl}^{-}, \mathrm{NO}_{3}^{-}$ and TSS.

During this sequence of successive storm flows, the amounts of SRP measured and exported at the watershed outlet closely fitted with the values calculated to estimate the SRP released by all the active zones (Tab. V). First of all, this result tends to show that the export of SRP at the outlet of the whole watershed can be due only to SRP released from the soils, especially from agricultural soils. Everything occurs as if SRP was not drastically controlled during the transfer (especially controlled by TSS). In the same way, the estimated concentrations of active areas in $\mathrm{NO}_{3}^{-}$and $\mathrm{Cl}^{-}$(typical of the subsurface component) closely fitted with their values measured at the outlet. These similarities between solutes validate our estimations.

In contrast, the TSS and PP concentrations at the outlet systematically exceeded the values calculated for the active zones, generally by a factor of between 3 and 5 . This phenomenon was attenuated during the erosive runoff storm flow (19th Jan. 97). The hydrological network contribution therefore appeared to be a determining factor in TSS and PP emissions for all these storm flows, by re-suspension of sediment or by the erosion of river banks. This result could explain why, while SRP or SP was predominant in runoff from the agricultural areas, (Tab. IV, Fig. 5), the forms of $\mathrm{P}$ at the outlet were mainly particulate $(70 \%$ on average annually, Tab. II).

\section{DISCUSSION}

The 302-ha rural basin studied is characterised by moderate exportation coefficients of $\mathrm{P}, \mathrm{NO}_{3}^{-}$and TSS, compared with the values reported for cropping zones in the literature [21]. This can be related to a relatively high proportion of forest land (1/3), the gentle relief (low erosion rate) and the small area artificially drained in the cultivated land. The levels of $\mathrm{P}$ measured in the springs were low enough to conclude that deep transfers are very limited. Overall, the cultural and soil conditions are not a priori favourable to SP transfer in this watershed. Both soluble (SP) and particulate phosphorus (PP) were exported at the outlet mainly during storm flows. The PP form represented $80 \%$ on average of the total $\mathrm{P}$, which is often the case for other watersheds $[27,56,66]$. The annual mean SP concentration over the period of study, which represents the immediately bioavailable fraction of TP, was close to the threshold for the onset of eutrophication of Lake Léman $\left(30 \mu \mathrm{g} \mathrm{L}^{-1}\right.$ [3]). SP was constantly made up of $70 \%$ SRP. By studying the variability in concentrations and fluxes of SRP and SP at different time steps and on different scales, and by comparison with the behaviour of $\mathrm{NO}_{3}^{-}, \mathrm{Cl}^{-}$and TSS, it was possible to establish the specific patterns of SP behaviour.

\subsection{The decoupling of SP and PP}

The standard hypothesis by which the erosion of active zones during storm-flow events is assumed to determine PP concentrations, which in turn control those of SP, was contradicted by at least 4 phenomena observed at different time steps:

(1) the interannual variability in exports at the outlet showed that SP and PP variability was not correlated; SP behaviour was similar to that of $\mathrm{NO}_{3}^{-}$and $\mathrm{Cl}^{-}$;

(2) before being combined in the hydrological network, the runoff from most of the hydrologically active areas of the watershed exhibited a phosphorus speciation predominated by the soluble forms, even during most of the high-flow periods;

(3) at the outlet of the whole basin, storm-flow events occurring during the beginning of the wet period always exhibited very high SP and SRP (up to $0.5 \mathrm{mg} \mathrm{P} \mathrm{L}^{-1}$ ); the same dynamics were observed in a cultivated sub-watershed;

(4) lastly, during the storm-flow events studied, the evolution of concentrations and fluxes of SP and PP were not coupled; 
the same phenomena was observed simultaneously both in the cultivated sub-watershed and at the outlet of the entire watershed.

These facts support the idea that SP or SRP can often migrate or originate independently of PP. The differences in behaviour are greatest during the storm flows of the early wet season: a limited supply of PP and TSS comes mainly from the hydrological network, while simultaneously soluble forms of P seem to be easily extracted and transferred from cultivated soils. However, in a succession of storm flows, the SP available for export decreases progressively, following the same behaviour as $\mathrm{NO}_{3}^{-}$and $\mathrm{Cl}^{-}$. Finally, we suggest that PP and SRP are emitted together only during highly erosive storm flows. This assumption is supported by other references $[11,38]$. PP stock in the hydrological network would only recharge itself during these highly erosive storm flows, only once or twice a year in our case.

\subsection{Soluble $P$ transfer during critical period}

The storm flows of the early wet season were characterised by exceptionally high peaks of SP and SRP concentration. To our knowledge, the only study reporting an annual orthophosphate concentration cycle was carried out by Davis and Keller [10]. These authors suggest that phosphorus is released differently depending on the source reservoirs. Kronvang [35] reports high PP exports during storm flows following a long low-flow period, and attributes this to SP storage in the hydrological network. In our case, our balance calculations and our analysis of a succession of early wet season storm flows support the hypothesis that the high mean concentrations of the SP and SRP were due to $P$ released from agricultural soils. We assume that, during this critical period, there is a coincidence between dominant subsurface transfer and high SP concentration in interstitial waters of agricultural soils. This explains the high concentrations and their maintenance during the recession phase in the agricultural sub-watershed and thus the exceptional annual SP peak in the entire watershed. These SP dynamics are very close to those of $\mathrm{NO}_{3}^{-}$or $\mathrm{Cl}^{-}$which are both strongly related to the soil content. But the similarity is limited to this kind of hydrological period. Thereafter, the SP only concentrates at the beginning of storm flows like PP [11].

Even if the SP released during the critical period contributes little to exports on a yearly basis (14\% in our watershed), these periods ought to be taken into account for at least two reasons: (1) firstly, because the occurrence of peaks coincides with a period of maximal receptivity in Lake Geneva with respect to phosphorus supply (Barroin, pers. commun.), and (2) secondly, because SP shows a great mobility in the landscape during these periods, in such a standard watershed (with respect to its soils and land use and a priori not particularly suitable for SP exports).

\subsection{Prospects}

The relative decoupling of the particulate and solution forms of $P$, the spatial discontinuity of transfers $[35,72]$, and the time and spatial variability in $\mathrm{P}$ speciation characterise the $\mathrm{P}$ dynamics of diffuse transfer in rural watersheds. These properties are a challenge for process-based modelling. They should also lead to careful interpretation of the data obtained at the outlet of large watersheds (large storage capacity of the hydrographic network) since the sources and mechanisms occurring in the active zones can be concealed by in-stream processes.

From an agronomic point of view, the risk of SP transfer tends to increase when agricultural practices enhance the soil water pathways (artificial drainage) or increase the soil $\mathrm{P}$ content of the cultivated horizon and its surface with minimum tillage practices [17, 63], mulching [34] and high $P$ inputs [57, 61]. Indeed, Giroux et al. [18] believe that if the soil P saturation rate goes beyond $20 \%$, the risk of SP emission is very high. The study carried out by Heckrath et al. [24], who set the Olsen-P limit at $60 \mathrm{mg} \mathrm{kg}^{-1}$ beyond which transfers increase, gives similar indications. The high SP contents measured over short periods during the autumn recharge of our watershed could correspond to premonitory signs of a spread of soluble transfers, if soil $P$ contents increase. Only by taking action aimed at managing the $\mathrm{P}$ budget is there a hope of decreasing soluble $\mathrm{P}$ in runoff considerably in the long term $[2,5,68]$. Recent fertilisation practices based on non-fertilisation policies [6] would help to achieve this goal.

Acknowledgements: We are grateful to Anne-Marie Wall (Service Linguistique, Unité Centrale de Documentation, INRA Jouy) for translating the manuscript and to Prof. Alan Cassell for his assistance during the corrections of the manuscript.

\section{REFERENCES}

[1] Baker J.L., Agricultural areas as nonpoint sources of pollution, in: Overcash M.R., Davidson J.M. (Eds.), Environmental impact of nonpoint source pollution, Ann Arbor Sci. (1980) 275-310.

[2] Cassell E.A., Dorioz J.M., Kort R.L., Hoffmann J.P., Meals D.W., Kirschtel D., Braun D.C., Watershed Modeling: Dynamics of Phosphorus Storage, Cycling, Transport and Export, J. Environ. Qual. 27 (1998) 293-298.

[3] C.I.P.E.L., Le Léman. Synthèse de 1957 à 1982, Commission Internationale pour la Protection des Eaux du Léman, Lausanne, 1984.

[4] C.I.P.E.L., Rapport de l'étude des pollutions diffuses dans le bassin lémanique, Commission Internationale pour la Protection des Eaux du Léman, Lausanne, 1988.

[5] Clausen J.C., Meals D.W., Cassell E.A., Estimation of the lag time for water quality response to BMPs, in National RCWP Symposium, Orlando, Florida, US. Environmental Protection Agency and US Department of Agriculture, 1992, EPA 625/R92/ 006, pp. 173-179.

[6] C.O.M.I.F.E.R., Aide au diagnostic et à la prescription de la fertilisation phosphatée et potassique des grandes cultures, 1995.

[7] Cooke G.W., Williams R.J.B., Significance of man-made sources of phosphorus: fertilizers and farming. The phosphorus involved in agricultural systems and possibilities of its movement into natural water, Water Res. 7 (1973) 19-33.

[8] Creed I.F., Band L.E., Foster N.W., Morrison I.K., Nicolson J.A., Semkin R.S., Jeffries D.S., Regulation of nitrate-N release from temperate forests: a test of the N flushing hypothesis, Water Resour. Res. 32 (1996) 3337-3354.

[9] Cros-Cayot S., Distribution spatiale des transferts de surface à l'échelle du versant. Contexte armoricain, Thèse de l'École Supérieure Agronomique de Rennes "Sciences de l'environnement", SDS 562, 1996.

[10] Davis J.S., Keller H.M., Biogeochemical parameters of streams and rivers - Discharge and seasonal related fluctuations, PhysioGéo. 9 (1984) 75-84. 
[11] Dorioz J.M., Ferhi A., Pollution diffuse et gestion du milieu agricole : transferts comparés de phosphore et d'azote dans un petit bassin versant agricole, Water Res. 28 (1994) 395-410.

[12] Dorioz J.M., Pelletier J., Benoit P., Propriétés physico-chimiques et biodisponibilité potentielle du phosphore particulaire selon l'origine des sédiments dans un bassin versant du Léman (France), Water Res. 32 (1998) 275-286.

[13] European Norm ISO 10304-1, Dosage des ions fluorure, chlorure, nitrite, orthophosphate, bromure, nitrate et sulfate dissous, par chromatographie des ions en phase liquide. Partie 1 : méthode applicable pour les eaux faiblement contaminées, Qualité de l'eau, AFNOR, 1995.

[14] European Norm EN 1189, Le dosage du phosphore. Qualité de l'eau, AFNOR, 1996.

[15] Flanagan D.C., Foster G.R., Storm pattern effect on nitrogen and phosphorus losses, in: surface runoff, Trans. ASAE 32 (1989) 535-544.

[16] Frere M.H., Ross J.D., Lane L.J., The nutrient submodel, in: Knisel W.G. (Ed.), C.R.E.A.M.S., A field scale model for Chemical, Runoff and Erosion from Agricultural Management Systems, Conservation Research Report, US, Department of agriculture, Washington DC, 1980, pp. 65-87.

[17] Gaylor J.D., Findlay W.I., Soil and phosphorus loss from conservation and conventional tillage, in: corn production, J. Environ. Qual. 24 (1995) 734-741.

[18] Giroux M., Carrier D., Beaudet P., Problématique et méthode de gestion des charges de phosphore appliquées aux sols agricoles en provenance des engrais de ferme, Agrosol 9 (1996) 36-45.

[19] Hamid S., Dray M., Ferhi A., Dorioz J.M., Traçage isotopique des mouvements de l'eau en terrain fluviatile: étude intégrée à l'échelle d'une parcelle et d'un bassin versant. Isotopes techniques, in: Water Resources Development, Symposium I.A.E.A., Viennes, 1987.

[20] Haygarth P.M., Jarvis S.C., Soil derived phosphorus in surface runoff from grazed grassland lysimeters, Water Res. 31 (1997) 140-148.

[21] Haygarth P.M., Jarvis S.C., Transfer of phosphorus from agricultural soils, Adv. Agron. 66 (1999) 195-249.

[22] Haygarth P.M., Hepworth L., Jarvis S.C., Forms of phosphorus transfer in hydrological pathways under grazed grassland, Eur. J. Soil Sci. 49 (1998) 65-72.

[23] Heathwaite A.L., Dils R.M., Characterizing phosphorus loss in surface and subsurface hydrological pathways, Sci. Total Environ. 251 (2000) 523-538.

[24] Heckrath G., Brokkes P.C., Poulton P.R., Goulding K.W.T., Phosphorus loading from soils containing different phosphorus concentrations in the Broadbalk Experiment, J. Environ. Qual. 24 (1995) 904-910.

[25] Hooda P.S., Moynagh M., Svoboda I.F., Edwards A.C., Anderson H.A., Sym G., Phosphorus loss in drainflow from intensively managed grassland soils, J. Environ. Qual. 28 (1999) 1235-1242.

[26] Izuno F.T., Sanchez C.A., Cale F.J., Bottcher A.B., Jones D.B., Phosphorus concentrations in drainage water in the Everglades agriculture area, J. Environ. Qual. 20 (1991) 608-619.

[27] Johnson A.H., Bouldin D.R., Goyette E.A., Hedges A.H., Phosphorus loss by stream transport from a rural watershed: quantities, processes and sources, J. Environ. Qual. 5 (1976) 148-157.

[28] Jones R.A., Lee G.F., Review: recent advances in assessing impact of phosphorus loads on eutrophication related to water quality, Water Res. 16 (1982) 503-515.

[29] Jordan-Meille L., Modes de transferts de phosphore d'origine diffuse dans un petit bassin versant rural lémanique, Thèse de l'École Polytechnique Fédérale de Lausanne "Génie rural", 1998, p. 1775.

[30] Jordan-Meille L., Dorioz J.M., Wang D., Analysis of the export of diffuse phosphorus from a small rural watershed, Agronomie 18 (1998a) 5-26.

[31] Jordan-Meille L., Dorioz J.M., Mathieu N., Approche expérimentale par crue artificielle de la participation du réseau hydrographique à l'exportation de phosphore par un petit bassin versant rural, Water Res. 32 (1998b) 1801-1810.

[32] Kauark Leite L.A., Réflexions sur l'utilité des modèles mathématiques dans la gestion de la pollution diffuse d'origine agricole, Thèse de l'École Nationale des Ponts et Chaussées "Sciences et techniques de l'environnement", École Nationale des Ponts et Chaussées Paris et CERGRENE Noisy le Grand, 1990.

[33] Kleinman P.J.A., Sharpley A.N., Moyer B.G., Elwinger G.F., Effect of mineral and manure phosphorus sources on runoff phosphorus, J. Environ. Qual. 31 (2002) 2026-2033.

[34] Koro N., Bernard C., Laverdière M.R., Contrôle du ruissellement, de l'érosion et des pertes de phosphore par les résidus de culture sous pluie simulée, Étude et Gestion des Sols 2 (1995) 173-182.

[35] Kronvang B., Sediment - associated phosphorus transport from two intensively farmed catchment areas, Soil erosion on agricultural land, 1990, pp. 313-330.

[36] Kronvang B., The export of particulate matter, particulate phosphorus and dissolved phosphorus from two agricultural river bassins: implications on estimating the non-point phosphorus load, Water Res. 26 (1992) 1347-1358.

[37] Loehr R.C., Characteristics and comparative magnitude of non point sources, J. Water Pollut. Cont. Fed. 46 (1974) 1849-1872.

[38] Logan T.J., The role of soil and sediment chemistry in modeling nonpoint sources of phosphorus, in: Overcash M.R., Davidson J.M. (Eds.), Environmental impact of nonpoint source pollution, Ann Arbor Sci. (1980) 189-208.

[39] Ludwig B., L'érosion par ruissellement concentré des terres cultivées du nord du bassin parisien : analyse de la variabilité des symptômes d'érosion à l'échelle du bassin versant élémentaire, Thèse de l'université de Strasbourg, 1992.

[40] McDowell R., Sharpley A., Folmar G., Phosphorus export from an agricultural watershed: linking source and transport mechanisms, J. Environ. Qual. 30 (2001) 1587-1595.

[41] Meybeck M., Carbon, nitrogen and phosphorus transport by world rivers, Am. J. Sci. 282 (1982) 401-405.

[42] Moléna J., Rôle de la nappe sur les transferts d'eau et de nitrate dans un bassin versant agricole. Étude expérimentale et modélisation, Thèse de l'Université de Rennes 1, INRA, 1999.

[43] Morel C., Plenchette C., Fardeau J.C., La fertilisation phosphatée raisonnée de la culture du blé, Agronomie 12 (1992) 565-579.

[44] Morel C., Cisse L., Plénet D., Pellerin S., Movement of phosphorus from topsoil to subsoil after decades of agricultural land use with increasing rates of annual P fertilisation, in: Proc. Vol. 2. Fifth Congress of the European Society for Agronomy, Nitra, The Slovak Republic, 1998, pp. 200-201.

[45] Mosimann T., Maillard A., Musy A., Neyroud J.A., Rüttimann M., Weisskopf P., Lutte contre l'érosion des sols cultivés. Guide pour la conservation des sols, Rapport thématique du programme national de recherche 'Utilisation des sols en Suisse', Berne Leibefeld, 1991.

[46] Muscutt A.D., Withers P.J.A., The phosphorus content of rivers in England and Wales, Water Res. 30 (1996) 1258-1268.

[47] Ng H.Y.F., Mayer T., Marsalek J., Phosphorus transport in runoff from a small agricultural watershed, Water Sci. Tech. 28 (1993) $451-460$

[48] Olsen S.R., Cole C.V., Watabane F.S., Dean L.A., Estimation of available phosphorus in soil by extraction with sodium bicarbonate, Circular No. 939, USDA, Washington, 1954.

[49] Pilleboue E., Origines, bilans et mécanismes de transfert du phosphore et de l'azote d'un bassin versant vers un lac, Thèse de l'Université de Paris VI, 1987.

[50] Raez G.J., Release of P in organic soils under aerovbic and anaerobic conditions, Can. J. Soil Sci. 59 (1979) 337-339.

[51] Römkens M.J., Nelson D.W., Phosphorus relationships in runoff from fertilized soils, J. Environ. Qual. 3 (1974) 10-13.

[52] Ryding S.O., Rast W., Uhlmann D., Clasen J., Somlyodo L., Le contrôle de l'eutrophisation des lacs et des réservoirs, Coll. Sciences de l'environnement, Masson Paris, UNESCO Paris, 1994. 
[53] Schoumans O.F., Groenendijk P., Modeling soil phosphorus leaching from agricultural land in the Netherlands, J. Environ. Qual. 29 (2000) 111-116.

[54] Sharpley A.N., The enrichment of soil phosphorus in runoff sediments, J. Environ. Qual. 99 (1980) 521-526.

[55] Sharpley A.N., Smith S.J., Prediction of soluble phosphorus transport in agricultural runoff, J. Environ. Qual. 18 (1989) 313-316.

[56] Sharpley A.N., Daniel T.C., Edwards D.R., Phosphorus movement in the landscape, J. Prod. Agric. 6 (1993) 492-500.

[57] Simard R.R., Cluis D., Ganbazo G., Beauchemin S., Phosphorus status of forest and agricultural soils from a watershed of high animal density, J. Environ. Qual. 24 (1995) 1010-1017.

[58] Simard R.R., Beauchemin S., Haygarth P.M., Potential for preferential pathways of phosphorus transport, J. Environ. Qual. 29 (2000) 97-105.

[59] Sims J.T., Simard R.R., Joern B.C., Phosphorus loss in agricultural drainage: historical pespective and current research, J. Environ. Qual. 23 (1998) 437-451.

[60] Smith S.J., Sharpley A.N., Ahuja L.R., Agricultural chemical discharge in surface water runoff, J. Environ. Qual. 22 (1993) 474 480.

[61] Smith R.V., Lennox S.D., Jordan C., Foy R.H., McHale E., Increase in soluble phosphorus transported in drainflow from a grassland catchment in response to soil phosphorus accumulation, Soil Use Manage. 11 (1995) 204-209.

[62] Stamm C., Flühler H., Gächter R., Leuenberger J., Wunderli H., Preferential transport of phosphorus in drained grassland soils, J. Environ. Qual. 27 (1998) 515-522.

[63] Staver K.W., Magette W.L., Tillage effect on phosphorus transport from atlantic coastal plain watersheds, Paper No. 88-2651, St Joseph, Mich., 1988.

[64] Strahler A.N., Hydrology, Handbook of applied hydrology, Chow V.T. (Eds.), McGraw-Hill, New-York, 1964.
[65] Strawczynski A., Pasquini F., Analyses comparatives inter-laboratoires. Campagne 2001, Commission Internationale pour la Protection des Eaux du Léman, Lausanne, 2002.

[66] Svendsen L.M., Kronvang B., Kristensen P., Graesbol P., Dynamics of phosphorus compounds in a lowland river system: importance of retention and non-point sources, Hydrol. Process. 9 (1995) 119-142.

[67] Syers J.K., Brownman M.G., Smillie G.W., Corey R.B., Phosphate sorption by soils evaluated by the Langmuir equation, Soil Sci Soc. Am. Proc. 37 (1973) 358-363.

[68] Ulen B., Drainage-associated losses of phosphorus and other nutrients from agricultural land following a conversion over to alternative production, in: Proc. International Workshop on sediments and phosphorus: Erosion and delivery, transport and fate of sediments and sediment-associated nutrients in watersheds, Silkeborg, Denmark, 1996, pp. 63-66.

[69] US Environmental Protection Agency, Clean Lakes Program Guidance Manuel, Non point sources loadings, Office of Water Regulations and Standards, Washington, EPA-440/5-81-003, 1980.

[70] Uusitalo R., Turtola E., Kauppila T., Lilja T., Particulate phosphorus and sediment in surface runoff and drainflow from clayed soils, J. Environ. Qual. 30 (2001) 589-595.

[71] Vansteelant J.Y., Trevisan D., Perron L., Dorioz J.M., Roybin D., Conditions d'apparition du ruissellement dans les cultures annuelles de la région lémanique. Relation avec le fonctionnement des exploitations agricoles, Agronomie 17 (1997) 65-82.

[72] Verhoff F.H., Melfi D.A., Yaksich S.M., An analysis of total phosphorus transport in river systems, Hydrobiologia 91 (1982) 241252.

[73] Yli-Halla M., Hartikainen H., Ekholm P., Turtola E., Puustinen M., Kallio K., Assessment of soluble phosphorus load in surface runoff by soil analysis, Agric. Ecosyst. Environ. 56 (1995) 53-62.

[74] Young R.A., Onstad C.A., Bosch D.D., Anderson P.W., AGNPS A nonpoint-source pollution model for evaluating agricultural watersheds, J. Soil Water Conserv. (1989) 168-173. 